\title{
The Relationship between Quality of Life with Demographic Variables of Elderly in Golestan Province-Iran
}

\author{
Fereshteh Farzianpour1* ${ }^{*}$ Abbas Rahimi Foroushani2 ${ }^{2}$ Abbas Badakhshan ${ }^{3 *}$, \\ Mahin Gholipour ${ }^{4}$ \\ ${ }^{1}$ Department of Health Management and Economics, School of Public Health, Tehran University of Medical \\ Sciences, Tehran, Iran \\ ${ }^{2}$ Department of Epidemiology and Biostatistics, School of Public Health, Tehran University of Medical Sciences, \\ Tehran, Iran \\ ${ }^{3}$ Department of Health Management and Economics, School of Public Health, Tehran University of Medical \\ Sciences, Tehran, Iran \\ ${ }^{4}$ Golestan Research Center of Gastroenterology and Hematology, Golestan University of Medical Sciences, \\ Gorgan, Iran \\ Email: ${ }^{*}$ farzianp@sina.tums.ac.ir, ${ }^{*}$ dr badakhshan@yahoo.com
}

Received 31 March 2015; accepted 26 April 2015; published 5 May 2015

Copyright (C) 2015 by authors and Scientific Research Publishing Inc.

This work is licensed under the Creative Commons Attribution International License (CC BY).

http://creativecommons.org/licenses/by/4.0/

(c) (1) Open Access

\section{Abstract}

Quality of life subscales was influenced by different factors including age, gender, and financial status and more importantly by health, education, financial and marital status. The main goal of this study was relationship between (QOL) with demographic variables of elderly in Golestan province-Iran. This research was an analytical cross study that conducted on 193 individuals going to Jahandidegan geriatric charity institution of Golestan-Iran. The data were collected from questionnaire SF-36 for QOL the elderly indicators through interviews and observation and then analyzed using SPSS V.17 Software. Among QOL dimensions, only general health status showed a significant association with supporting organizations covering status $(P=0.01)$. The relationship between QOL with current employment status in both genders was observed.

\section{Keywords}

Quality of Life, Elderly, Questionnaire (SF36), Variables Demographic

\footnotetext{
${ }^{*}$ Corresponding authors.
}

How to cite this paper: Farzianpour, F., Foroushani, A.R., Badakhshan, A. and Gholipour, M. (2015) The Relationship between Quality of Life with Demographic Variables of Elderly in Golestan Province-Iran. Health, 7, 507-513. 


\section{Introduction}

More than 8\% of Iran's population are elderly. The greatest challenge in this generation is improvement of health and QOL [1]. QOL subscales were influenced by different factors including age, gender, and financial status and more importantly by health, education, financial and marital status [2]. Elderly people’s health and QOL, when compared with other age groups, are influenced by several factors such as physical, psychological, social and cultural rights [3]; so that when considering the elderly's health assessment and promotion, the knowledge of an entire health team shall be also considered since it is important for health professionals to work in multidisciplinary and multidimensional teams. Regarding the elderly care, it is necessary to estimate the maintenance of QOL, so that the whole human aging process is considered always seeking for the possibilities of prevention, maintenance and rehabilitation of their health condition [4]. Thus, as the human aging process is inevitable, it is essential that the health care provided to the elderly people shall be increasingly directed to these age group particularities, allowing them to experience a higher quality period of life, considering that the higher risk of complications arises in this stage of life. In order to meet the increasing demands of an aging population, a National Policy for the Elderly (NPE) was created based on UHS regulations, whose goal is to ensure the social rights of the elderly, create conditions to promote their autonomy, integration and effective participation in society [5]. Based on these perspectives, it is a function of health policies to provide aging people with the best possible health condition, which implies maintenance of their QOL. Thus, in 2006 it was implemented a National Health Policy for the Elderly (NHPE) which defined the Primary Health Care (PHC) as an entry point to the elderly's health care and a reference to system of specialized health services of medium and high complexity [6]. World Health Organization reported that there were more than 600 million elderly individuals in the world [7]; a figure which will double by 2025 and will reach 2 billion people by 2050 [8] [9]. The immense changes in cultural, socioeconomic and demographic aspects of Iranian society during the last few decades have given rise to an increase in the elderly population [10]. This study aimed to assess the QOL using the SF36 questionnaire and, while examining the impact of demographic variables of elderly and the relationship between QOL and environmental conditions. The novelty of this study was relationship between (QOL) with demographic variables and environmental conditions of elderly in Golestan province-Iran.

\section{Methods}

This research was an analytical cross-sectional study. The population society includes the elderly over 65 years in Golestan Province. This Research was approved by Vice Chancellor for Research of Tehran University of Medical Sciences and Research and Ethics Committee, no 19430-123225 in the 27/03/2012.

In the first phase, all population of the elderly in nursing centers in Golestan province was calculated. Then a number of samples were selected, from the population that the nursing centers cover them. Sampling was in the way that each nursing home was considered as a cluster and simple random sampling within each cluster was done. In this study of 193 elderly people aged over 65 years admitted of the charity Jahandidegan Golestan-Iran. Interviewed Questionnaire (Short Form Health Survey (SF-36)-Iranian Version) [11] and questions on demographic and background factors which were completed through face-to-face interviews. The SF-36 questionnaire has been translated and used in over 50 countries all over the world including Iran. The questionnaire consists of two major scales: the physical component and the mental component. The SF-36 also consisting 8 subscales (domains): physical functioning, Mobility Restricts, bodily pain, genera health, vitality, social functioning, and emotional problems and mental health. Each of these 8 dimensions may be scored from 0 through 100. Scoring is performed according to criteria of SF-36 standards, with higher scores indicating better function [11]. Data were entered and analyzed in SPSSV 0.17, using non-parametric Mann-Whitney U test and Kruskal-Wallis test. Then multiple regressions were performed.

\section{Results}

In this study $17.83 \%$ of the elderly were men and 82.16 were women. $38.4 \%$ of these people were singles, $20.52 \%$ of them illiterate. 92.93 percent insurance, 7.06 percent without any support services. In terms of employment of participants also 5.29 percent were unemployed (Table 1). Analysis of the data showed that 46.4 percent of men were living in cities and 53.6 percent of them were living in villages. These values are 88 and 12 percent for women. Table 2 showed a significant difference in mean physical function in both male and female 
F. Farzianpour et al.

Table 1. The relationship between quality of life with demographic variables of elder lies in Golestan Province-Iran 2014.

\begin{tabular}{|c|c|c|c|c|c|c|c|c|c|c|c|c|c|c|c|}
\hline \multicolumn{5}{|c|}{ Gender } & \multicolumn{3}{|c|}{ Age } & \multicolumn{3}{|c|}{ Residence } & \multicolumn{5}{|c|}{ Marital } \\
\hline \multicolumn{2}{|c|}{ Dimension } & Male & Female & Total & $60-64$ & $65 \geq$ & Total & Urban & Rural & Total & Single & Married & Divorced & Widow & Total \\
\hline \multirow{4}{*}{ 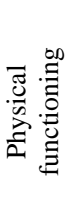 } & Lower & 5 & 60 & 65 & 55 & 12 & 62 & 50 & 12 & 62 & 3 & 25 & 2 & 34 & 64 \\
\hline & Normal & 8 & 36 & 44 & 44 & 1 & 45 & 35 & 7 & 42 & 5 & 32 & 1 & 6 & 44 \\
\hline & Hipper & 20 & 54 & 74 & 2 & 71 & 73 & 57 & 14 & 71 & 2 & 55 & 3 & 14 & 74 \\
\hline & Chi-square & & 0.13 & & & 0.01 & & & 0.916 & & & & 0.01 & & \\
\hline \multirow{4}{*}{ 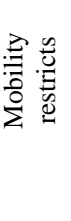 } & Lower & 11 & 92 & 103 & 92 & 13 & 105 & 92 & 10 & 102 & 5 & 51 & 3 & 43 & 102 \\
\hline & Normal & 4 & 5 & 9 & 9 & 0 & 9 & 1 & 7 & 8 & 0 & 7 & 0 & 2 & 9 \\
\hline & Hipper & 18 & 55 & 73 & 70 & 2 & 72 & 51 & 16 & 67 & 5 & 56 & 3 & 90 & 73 \\
\hline & Chi-square & & 0.06 & & & 0.046 & & & 0.01 & & & & 0.03 & & \\
\hline \multirow{4}{*}{ 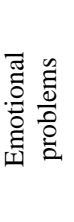 } & Lower & 5 & 61 & 66 & 11 & 67 & 54 & 9 & 63 & 5 & 25 & 25 & 1 & 33 & 64 \\
\hline & Normal & 1 & 1 & 2 & 0 & 2 & 2 & 0 & 2 & 0 & 2 & 2 & 0 & 0 & 2 \\
\hline & Hipper & 27 & 87 & 114 & 4 & 114 & 85 & 24 & 109 & 5 & 86 & 86 & 4 & 20 & 115 \\
\hline & Chi-square & & 0.013 & & & 0.09 & & & 0.363 & & & & 0.01 & & \\
\hline \multirow{4}{*}{ 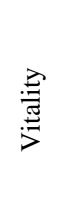 } & Lower & 0 & 23 & 23 & & & & 21 & 1 & 22 & 0 & 9 & 1 & 13 & 23 \\
\hline & Normal & 14 & 76 & 90 & & & & 69 & 22 & 91 & 8 & 52 & 2 & 28 & 90 \\
\hline & Hipper & 19 & 53 & 72 & & & & 54 & 10 & 64 & 2 & 53 & 3 & 13 & 71 \\
\hline & Chi-square & 0.012 & & & & & & 0.078 & & & 0.007 & & & & \\
\hline \multirow{4}{*}{ 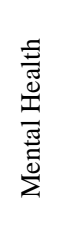 } & Lower & 1 & 20 & 21 & 19 & 1 & 20 & 21 & 0 & 21 & 1 & 10 & 2 & 7 & 20 \\
\hline & Normal & 11 & 70 & 81 & 71 & 11 & 82 & 67 & 13 & 80 & 1 & 51 & 1 & 28 & 81 \\
\hline & Hipper & 21 & 62 & 83 & 81 & 3 & 84 & 56 & 20 & 76 & 8 & 53 & 3 & 19 & 83 \\
\hline & Chi-square & & 0.037 & & & 0.58 & & & 0.018 & & & & 0.066 & & \\
\hline \multirow{4}{*}{ 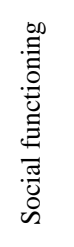 } & Lower & 5 & 38 & 43 & 8 & 7 & 45 & 34 & 8 & 42 & 3 & 17 & 1 & 21 & 42 \\
\hline & Normal & 12 & 21 & 33 & 31 & 2 & 33 & 21 & 9 & 30 & 0 & 23 & 2 & 8 & 33 \\
\hline & Hipper & 16 & 93 & 109 & 102 & 6 & 108 & 89 & 16 & 105 & 7 & 74 & 3 & 25 & 109 \\
\hline & Chi-square & & 0.008 & & & 0.105 & & & 0.187 & & & & 0.019 & & \\
\hline \multirow{4}{*}{ 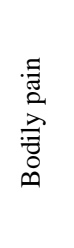 } & Lower & 1 & 29 & 30 & 24 & 7 & 31 & 26 & 2 & 28 & 3 & 10 & 2 & 15 & 30 \\
\hline & Normal & 8 & 49 & 57 & 50 & 5 & 55 & 45 & 11 & 56 & 3 & 31 & 2 & 17 & 53 \\
\hline & Hipper & 24 & 74 & 98 & 97 & 3 & 100 & 73 & 20 & 93 & 4 & 73 & 2 & 22 & 101 \\
\hline & Chi-square & & 0.644 & & & 0.017 & & & 0.225 & & & & 0.002 & & \\
\hline \multirow{4}{*}{ 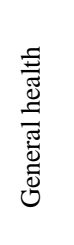 } & Lower & 0 & 27 & 27 & 21 & 5 & 26 & 19 & 5 & 24 & 5 & 6 & 3 & 12 & 26 \\
\hline & Normal & 23 & 61 & 84 & 78 & 6 & 84 & 58 & 22 & 80 & 2 & 52 & 2 & 25 & 82 \\
\hline & Hipper & 10 & 61 & 74 & 72 & 4 & 76 & 67 & 6 & 73 & 3 & 56 & 1 & 16 & 76 \\
\hline & Chi-square & 0.002 & & & 0.072 & & & 0.009 & & & 0.001 & & & & \\
\hline
\end{tabular}




\section{Continued}

\begin{tabular}{|c|c|c|c|c|c|c|c|c|c|c|c|c|c|c|c|c|c|c|c|c|c|c|c|c|c|c|}
\hline \multirow{2}{*}{\multicolumn{2}{|c|}{ Dimension }} & \multicolumn{8}{|c|}{ Education } & \multicolumn{11}{|c|}{ Organizations support services } & \multicolumn{6}{|c|}{ Employment } \\
\hline & & 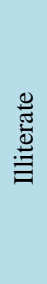 & $\stackrel{\vec{\Xi}}{\Xi}$ & 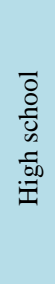 & 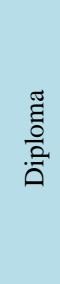 & 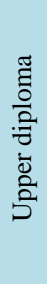 & $\mathscr{\oplus}$ & 퓽 & 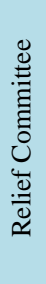 & $\frac{\stackrel{0}{\overparen{C}}}{3}$ & 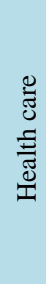 & 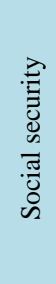 & 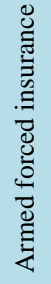 & 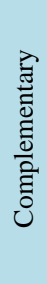 & $\stackrel{\breve{\Xi}}{Ð}$ & 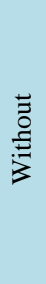 & 즁 & 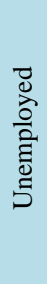 & 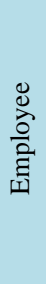 & $\underset{\text { 嘋 }}{\stackrel{\Xi}{\Xi}}$ & 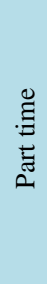 & 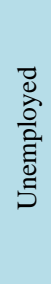 & 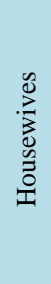 & 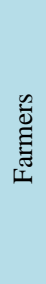 & $\underset{\mathscr{d}}{\mathscr{U}}$ & 쥼 \\
\hline \multirow{4}{*}{ 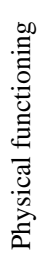 } & Lower & 2 & 17 & 13 & 14 & 1 & 0 & 67 & 7 & 0 & 29 & 16 & 4 & 1 & 2 & 5 & 64 & 2 & 1 & 0 & 5 & 1 & 53 & 2 & 3 & 67 \\
\hline & Normal & 7 & 20 & 10 & 5 & 1 & 0 & 43 & 1 & 2 & 14 & 13 & 3 & 2 & 2 & 5 & 42 & 0 & 0 & 3 & 1 & 1 & 28 & 2 & 6 & 41 \\
\hline & Hipper & 10 & 31 & 18 & 13 & 4 & 2 & 78 & 3 & 1 & 25 & 35 & 6 & 0 & 4 & 3 & 77 & 2 & 2 & 6 & 8 & 1 & 40 & 7 & 10 & 76 \\
\hline & Chi-square & \multicolumn{7}{|c|}{0.069} & \multicolumn{9}{|c|}{0.111} & \multicolumn{9}{|c|}{0.137} \\
\hline \multirow{4}{*}{ 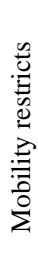 } & Lower & 26 & 36 & 22 & 19 & 3 & 1 & 107 & 8 & 2 & 37 & 33 & 7 & 2 & 5 & 8 & 102 & 2 & 1 & 5 & 7 & 2 & 78 & 1 & 9 & 103 \\
\hline & Normal & 4 & 1 & 2 & 1 & 0 & 1 & 9 & 1 & 1 & 2 & 5 & 0 & 0 & 0 & 0 & 9 & 0 & 2 & 0 & 0 & 0 & 3 & 1 & 2 & 8 \\
\hline & Hipper & 9 & 31 & 17 & 14 & 3 & 0 & 74 & 2 & 0 & 29 & 27 & 6 & 1 & 3 & 5 & 73 & 3 & 0 & 4 & 7 & 1 & 40 & 9 & 8 & 72 \\
\hline & Chi-square & \multicolumn{7}{|c|}{0.046} & \multicolumn{9}{|c|}{0.545} & \multicolumn{9}{|c|}{0.01} \\
\hline \multirow{4}{*}{ 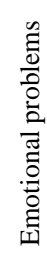 } & Lower & 18 & 18 & 18 & 11 & 1 & 0 & 66 & 4 & 1 & 31 & 17 & 4 & 0 & 2 & 4 & 63 & 1 & 1 & 0 & 2 & 1 & 55 & 2 & 3 & 65 \\
\hline & Normal & 0 & 1 & 0 & 1 & 0 & 0 & 2 & 0 & 0 & 0 & 0 & 0 & 0 & 0 & 2 & 2 & 0 & 0 & 1 & 0 & 0 & 0 & 0 & 0 & 1 \\
\hline & Hipper & 21 & 49 & 22 & 20 & 5 & 2 & 119 & 7 & 2 & 36 & 47 & 8 & 3 & 6 & 7 & 116 & 3 & 2 & 8 & 12 & 1 & 65 & 9 & 16 & 116 \\
\hline & Chi-square & \multicolumn{7}{|c|}{0.434} & \multicolumn{9}{|c|}{0.002} & \multicolumn{9}{|c|}{0.001} \\
\hline \multirow{4}{*}{ 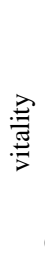 } & Lower & 8 & 4 & 4 & 8 & 0 & 0 & 24 & 2 & 0 & 12 & 4 & 2 & 1 & 0 & 1 & 22 & 1 & 0 & 0 & 2 & 2 & 17 & 0 & 2 & 24 \\
\hline & Normal & 20 & 33 & 20 & 14 & 4 & 1 & 92 & 4 & 3 & 33 & 29 & 6 & 1 & 5 & 9 & 90 & 1 & 3 & 3 & 7 & 0 & 62 & 4 & 11 & 91 \\
\hline & Hipper & 11 & 34 & 17 & 12 & 2 & 1 & 74 & 5 & 0 & 23 & 32 & 5 & 1 & 3 & 3 & 72 & 3 & 0 & 6 & 5 & 1 & 42 & 7 & 6 & 70 \\
\hline & Chi-square & \multicolumn{7}{|c|}{0.291} & \multicolumn{9}{|c|}{0.382} & \multicolumn{9}{|c|}{0.091} \\
\hline \multirow{4}{*}{ 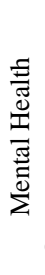 } & Lower & 3 & 5 & 8 & 5 & 0 & 0 & 21 & 1 & 0 & 8 & 4 & 1 & 1 & 1 & 3 & 19 & 0 & 0 & 0 & 1 & 2 & 13 & 0 & 3 & 19 \\
\hline & Normal & 17 & 29 & 16 & 19 & 2 & 1 & 84 & 4 & 3 & 31 & 29 & 8 & 1 & 1 & 4 & 81 & 3 & 3 & 1 & 4 & 0 & 62 & 3 & 7 & 83 \\
\hline & Hipper & 19 & 34 & 17 & 10 & 4 & 1 & 85 & 6 & 0 & 29 & 32 & 4 & 1 & 6 & 6 & 84 & 2 & 0 & 8 & 9 & 1 & 46 & 8 & 9 & 83 \\
\hline & Chi-square & \multicolumn{7}{|c|}{0.458} & \multicolumn{9}{|c|}{0.337} & & & & & 0.00 & & & & \\
\hline$\infty$ & Lower & 16 & 15 & 8 & 6 & 0 & 0 & 45 & 5 & 0 & 14 & 17 & 2 & 2 & 1 & 3 & 44 & 0 & 0 & 4 & 3 & 2 & 32 & 1 & 3 & 45 \\
\hline .0ํำ & Normal & 10 & 13 & 6 & 3 & 0 & 1 & 33 & 3 & 3 & 9 & 13 & 0 & 0 & 1 & 2 & 31 & 2 & 2 & 0 & 5 & 0 & 16 & 1 & 4 & 30 \\
\hline 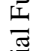 & Hipper & 13 & 40 & 27 & 25 & 6 & 1 & 112 & 3 & 0 & 45 & 35 & 11 & 1 & 6 & 8 & 109 & 3 & 1 & 5 & 6 & 1 & 73 & 9 & 12 & 110 \\
\hline n & Chi-square & & & & 0.022 & & & & & & & & .008 & & & & & & & & & 0.06 & & & & \\
\hline
\end{tabular}




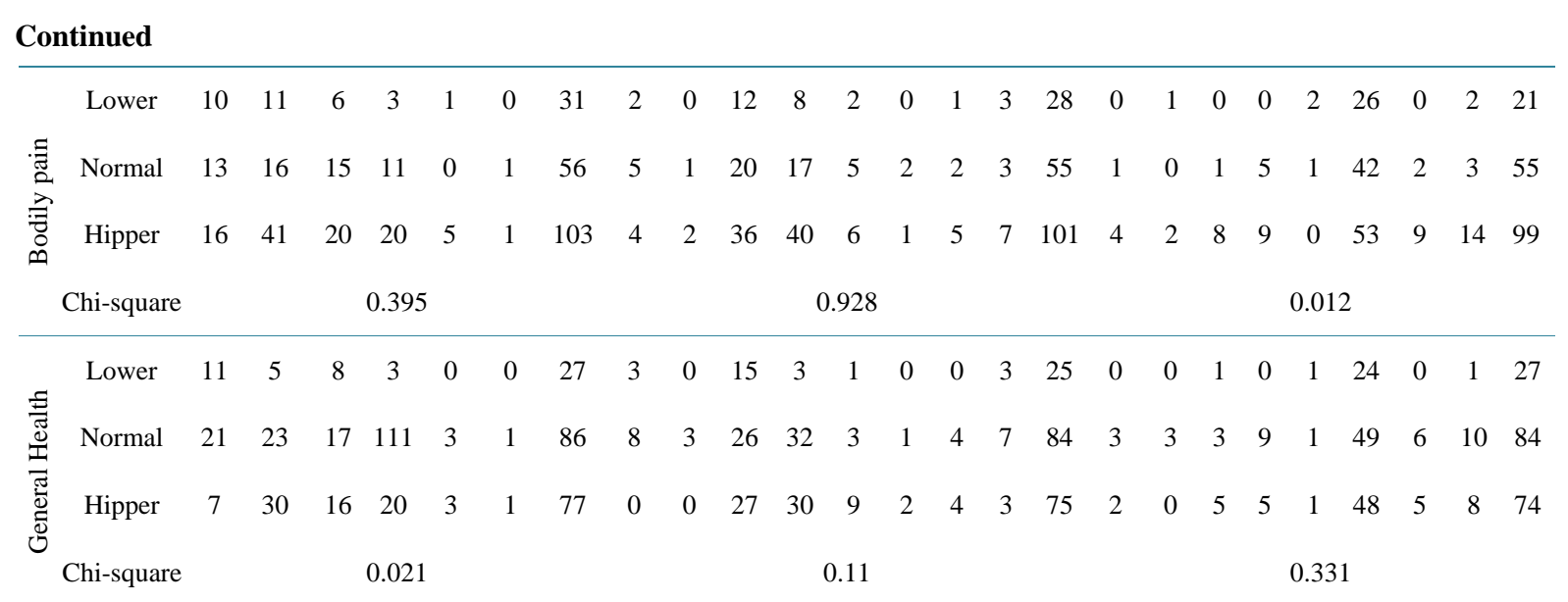

Table 2. The relationship between QOL with demographic variables of elderly in Golestan province-Iran 2014.

\begin{tabular}{|c|c|c|c|c|c|c|}
\hline $\begin{array}{c}\text { Variables } \\
\text { QOL }\end{array}$ & Gender & Residence & Marital & Employment & $\begin{array}{l}\text { Organizations } \\
\text { support services }\end{array}$ & Education \\
\hline $\begin{array}{l}\text { Physical } \\
\text { functioning }\end{array}$ & $\mathrm{P}=0.007$ & $P=0.866$ & $\mathrm{P}=0.01$ & & & $P=0.019$ \\
\hline $\begin{array}{l}\text { Mobility } \\
\text { restricts }\end{array}$ & $\begin{array}{c}P=0.02 \\
C I=9.60-40.36\end{array}$ & $\begin{array}{c}\mathrm{P}=0.006 \\
\mathrm{CI}=-37.17-6.35\end{array}$ & $P=0.001$ & $\mathrm{P}=0.031$ & & \\
\hline $\begin{array}{l}\text { Emotional } \\
\text { problems }\end{array}$ & $\begin{array}{c}\mathrm{P}=0.01 \\
\mathrm{CI}=11.32-38.55\end{array}$ & $\begin{array}{c}\mathrm{P}=0.213 \\
\mathrm{CI}=-26.49-5.17\end{array}$ & $\mathrm{P}=0.001$ & $\mathrm{P}=0.005$ & & \\
\hline Vitality & $\begin{array}{c}\mathrm{P}=0.02 \\
\mathrm{CI}=4.12-17.33\end{array}$ & $\begin{array}{c}\mathrm{P}=0.883 \\
\mathrm{CI}=-7.15-6.15\end{array}$ & $\mathrm{P}=0.009$ & $\mathrm{P}=0.018$ & & \\
\hline Mental health & $\begin{array}{c}\mathrm{P}=0.01 \\
\mathrm{CI}=4.65-18.10\end{array}$ & $\begin{array}{c}P=0.01 \\
C I=-14.30-4.44\end{array}$ & 0.144 & $\mathrm{P}=0.005$ & & \\
\hline $\begin{array}{c}\text { Social } \\
\text { functioning }\end{array}$ & $\mathrm{P}=0.142$ & $\begin{array}{c}\mathrm{P}=0.012 \\
\mathrm{CI}=2.42-18.86\end{array}$ & 0.075 & & & $\mathbf{P}=0.01$ \\
\hline Bodily pain & $\begin{array}{c}\mathrm{P}=0.024 \\
\mathrm{CI}=0.92-12.49\end{array}$ & $\begin{array}{c}\mathrm{P}=0.736 \\
\mathrm{CI}=-8.03-5.27\end{array}$ & $\mathrm{P}=0.004$ & $\mathrm{P}=0.007$ & & $P=0.031$ \\
\hline General health & $\begin{array}{c}\mathrm{P}=0.630 \\
\mathrm{CI}=-3.09-5.08\end{array}$ & $\begin{array}{c}\mathrm{P}=0.013 \\
\mathrm{CI}=0.44-12.67\end{array}$ & $\mathrm{P}=0.001$ & & $\mathrm{P}=0.01$ & $\mathbf{P}=\mathbf{0 . 0 1}$ \\
\hline
\end{tabular}

$=0.007$. Similarly, the mean of other dimensions of QOL was compared in two groups of male and female sexuality. In Similar analysis mobility restricts average in both men and women groups are also physical functioning illustrates that the relationship is significant $(\mathrm{P}=0.002, \mathrm{CI}=9.60-40.36)$. Emotional problems mean in both men and women has a significant correlation $(\mathrm{P}=0.001, \mathrm{CI}=11.32-38.55)$. In assessment of the mean sexual vitality in both men and women groups T-test P-value was equal to 0.02 and confidence interval was 4.12 - 17.33, which was significant. Investigating the mean emotional problems, mobility restricts, mental health, social functioning, bodily pain and mean general health with residence were significant $\mathrm{P}<0.05$.

Between different dimensions of QOL and marital status it was found out that the dimensions of physical functioning, mobility restricts, emotional problems, vitality, bodily pain and general health (had a significant relationship $<0.05$. So dimensions of physical functioning, social functioning, bodily pain and general health in order to value ( $\mathrm{P}=0.019)$, $(\mathrm{P}=0.01),(\mathrm{P}=0.031$ and $(\mathrm{P}=0.01)$ with education status had a significant relationship.

Among QOL dimensions just general health with the status of supporting showed a significant association to each other $(P=0.01)$. The relationship between $\mathrm{QOL}$ and current employment status it was seen that that the mobility restricts $(P=0.031)$, emotional problems $(P=0.005)$, vitality $(P=0.018)$, mental health $(P=0.005)$ and bodily pain $(\mathrm{P}=0.007)$ were significantly associated and other aspects relationships with these variables were not significant (Table 2). 


\section{Discussion}

Our findings support previously described beneficial effects of the counseling model on the elderly QOL in the cities of Masjed solaiman [9], Zahedan [12] and Shahinshar [13], Bandar Abbas [14], Iran. The mean QOL scores measured in the elderly population, in other countries were much higher than the results obtained in Iran [15]. The QOL subscales were influenced by differentfactors including age, gender, financial status and moreImportantly by education, financial and marital status asother studies showed [9] [14]-[17]. Therefore, it is importantto inform the elderly population of the behavioral modificationsbenefits of the QOL. The study of Haj Bagheri also found clear connections between disability and gender and the higher rate of failure in women [18] Gureje and colleagues also point out that the bodily pain which can lead to reduced QOL was higher in women [19] that this issue could be due to a greater incidence of chronic disabling diseases in women than in men [19]. However the study of Abdollahi and Mohammad Poor found that women in vitality and mobility restrict aspects were better than men [20]. In the study of Jafarzadeh and colleagues in Sabzevar only in terms of physical pain among men and women, significant differences were observed [21].

\section{Conclusions}

It seems that dimensions of QOL are more related to gender and relative superiority of men over women. So the policy makers of health sector should pay more attention to the social factors affecting health such as education, housing and the physical functioning. Particularly that the illiteracy rate among women was higher than men, and also a lot of them were housewives that were an unpaid work and therefore didn't create any sense of security. It also seems that due to physiological and anatomical features of women and men, physically activity facilities for women should have provided more and economic and social barriers to be eliminated as soon as possible. It seems that some restrictive measures such as the establishment of special parks in Golestan Province or some other metropolises are not an appropriate strategy to address this deficiency. Relating with different dimensions of (QOL) and age of participants, it is seen that with increasing age of the participants in terms of bodily pain, mobility restricts and mental health increases, this is necessary for authorities to pay attention to these issues and programs to improve their physical activities and specially their mental health.

Overall, this study and other studies suggest that aging alone was not particularly effective on the QOL dimensions especially on mental health and other aspects of life in the elderly.

\section{Limitations of the Study}

Limitations of the study was related to the elderly limitations to understand the SF36 questionnaire was questions that took a lot of time of researchers to access to the most appropriate answer.

\section{Acknowledgements}

We appreciate the kind collaboration of Mr.Salmani and Mr.Ahangari Golestan Research Center of Gastroenterology and Hepatology, Golestan University of Medical Sciences, So all the elderly in Golestan Province for careful completion of our questionnaires.

\section{References}

[1] Malekafzali, H., Baradaran Eftekhari, M., Hejazi, F., Khojasteh, T., Noot, R.H., Falahat, K., et al. (2010) The Effectiveness of Educational Intervention in the Health Promotion in Elderly People. Iranian Journal of Public Health, 39, 18-23.

[2] Farzianpour, F., Farokhi, B., Shojaei, S., Shafi, M. and Manafi, F. (2014) Status of the Elderly Health Care Costs. American Journal of Agricultural and Biological Sciences, 9, 147-152. http://www.thescipub.com/ajabs.toc http://dx.doi.org/10.3844/ajabssp.2014.147.152

[3] Ciosak, S.I., Braz, E., Costa, M.F.B.N.A., Gonçalves, N., Nakano, R., Rodrigues, J., Alencar, R.A., et al. (2011) Senescence and Senility: The New Paradigm in Primary Health Care. Revista da Escola de Enfermagem da USP, 45, 1763-1768. http://www.scielo.br/pdf/reeusp/v45nspe2/22.pdf http://dx.doi.org/10.1590/S0080-62342011000800022

[4] Brazil Ministry of Health (2010) Health Care Secretariat. Primary Health Care Department, Primary Care Assessment. Tool Manual, Brasilia. http://189.28.128.100/dab/docs/publicacoes/geral/manual_instrumento_avaliacao.pdf 
[5] Brazil Ministry of Health (2007) Health Care Secretariat. Primary Health Care Department, Aging and Health of the Elder, Brasilia. http://bvsms.saude.gov.br/bvs/publicacoes/abcad19.pdf

[6] Marin, M.J.S., Marques, A.P.M.F., Feres, B.O.M., Saraiva, A.K.H. and Druzian, S. (2008) Health Attention to the Elderly: Actions and Perspectives of Professionals. Revista Brasileira de Geriatria e Gerontologia, 11, 245-258. http://revista.unati.uerj.br/scielo.php?script=sci_arttext\&pid=S1809-98232008000200009\&lng=pt

[7] Farzianpour, F., Arab, M., Hosseini, S.M., Pirozi, B. and Hosseini, S. (2012) Evaluation of Quality of Life of the Elderly Population Covered by Healthcare Centers of Marivan and the Influencing Demographic and Background Factors in 2010. Iranian Red Crescent Medical Journal, 14, 697-698. http://dx.doi.org/10.5812/ircmj.1834

[8] Lutz, W., Sanderson, W. and Scherbov, S. (2008) The Coming Acceleration of Global Population Ageing. Nature, 451, 716-719. http://dx.doi.org/10.1038/nature06516

[9] Farzianpour, F., Hosseini, S.H., Rostami, M., Pordanjani, S.H. and Hosseini, S.M. (2012) Quality of Life of the Elderly Residents. American Journal of Applied Sciences, 9, 71-74. http://dx.doi.org/10.3844/ajassp.2012.71.74

[10] Farzianpour, F. and Tajvar, M. (2004) Elderly Health and a Review on Different Aspects of Their Life. Nasle Farda and Arjmand Press, Tehran.

[11] Montazeri, A., Goshtasebi, A., Vahdaninia, M. and Gandek, B. (2005) The Short Form Health Survey (SF-36): Translation and Validation Study of the Iranian Version. Quality of Life Research, 14, 875-882. http://dx.doi.org/10.1007/s11136-004-1014-5

[12] Salari, A. (2003) The Impact of Follow up Counseling Model on the Elderly Life in Zahedan. Tabibe Shargh, 4.

[13] Albokordi, M., Ramazani, M. and Orayzi, F. (2005) The Elderly Life Quality in Shahinshahr City in 2003. General Physician, 4.

[14] Aghamolaei, T., Tavafian, S.S. and Zare, S. (2010) Health Related Quality of Life in Elderly People Living in Bandar Abbas, Iran: A Population-Based Study. Acta Medica Iranica, 48, 185-191.

[15] Tsai, S.Y., Chi, L.Y., Lee, L.S. and Chou, P. (2004) Health-Related Quality of Life among Urban, Rural, and Island Community Elderly in Taiwan. Journal of the Formosan Medical Association, 103, 196-204.

[16] US Department of Health and Human Services (2008) Physical Activity Guidelines Advisory Committee Report. http://www.health.gov/PAGuidelines/Report/

[17] Abbasimoghadam, M.A., Dabiran, S., Safdari, R. and Djafarian, K. (2009) Quality of Life and Its Relation to Sociodemographic Factors among Elderly People Living in Tehran. Geriatrics \& Gerontology, 9, 270-275. http://dx.doi.org/10.1111/j.1447-0594.2009.00532.x

[18] Adib-Hajbaghery, M. and Akbari, H. (2009) The Severity of Old Age Disability and Its Related Factors. KAUMS Journal (FEYZ), 13, 225-234.

[19] Gureje, O., Ogunniyi, A., Kola, L. and Afolabi, E. (2006) Functional Disability in Elderly Nigerians: Results from the Ibadan Study of Aging. Journal of the American Geriatrics Society, 54, 1784-1789. http://dx.doi.org/10.1111/j.1532-5415.2006.00944.x

[20] Abdollahi, F. and Mohammadpour, R.A. (2013) Health Related Quality of Life among the Elderly Living in Nursing Home and Homes. Journal of Mazandaran University of Medical Sciences, 23, 20-25.

[21] Jafarzade, F.M., Behnam, V.H. and Vahedian, S.M. (2010) The Quality of Life of the Elderly in Sabzevar, Iran. Journal of Sabzevar University of Medical Sciences, 17, 213-217. 